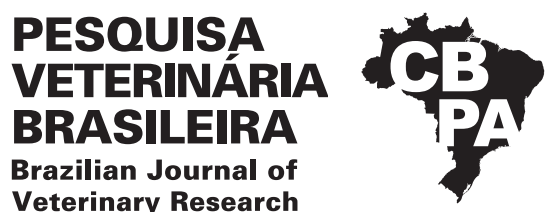

Pesq. Vet. Bras. 41:e06575, 2021

DOI: 10.1590/1678-5150-PVB-6575

Original Article

Small Animal Diseases

ISSN 0100-736X (Print)

ISSN 1678-5150 (Online)

\title{
Comparison between hematological and biochemical changes caused by conventional and metronomic chemotherapies in the treatment of canine transmissible venereal tumor
}

\author{
Paulo H. Braz ${ }^{2 *}$ (D) and Carolina P. Marinho ${ }^{3}$
}

\begin{abstract}
Braz P.H. \& Marinho C.P. 2021. Comparison between hematological and biochemical changes caused by conventional and metronomic chemotherapies in the treatment of canine transmissible venereal tumor. Pesquisa Veterinária Brasileira 41:e06575, 2021. Instituto Federal Farroupilha, Frederico Westphalen, RS 98400-000, Brazil. E-mail: paulo.braz@iffarroupilha.edu.br

This study aimed to report the hematological and biochemical changes caused by conventional and metronomic chemotherapies, using vincristine sulfate to treat canine Transmissible Venereal Tumor (TVT). Twelve dogs were selected, six of them for the group receiving conventional chemotherapy (G1), and six dogs for the group receiving metronomic chemotherapy (G2). The G1 group received vincristine sulfate once a week at the dose of $0.75 \mathrm{mg} / \mathrm{m}^{2}$ until the tumor had disappeared with treatment, and the G2 group was treated with vincristine sulfate three times a week at the dose of $0.25 \mathrm{mg} / \mathrm{m}^{2}$ until the tumor had disappeared. Before and after chemotherapy treatment, hematological and biochemical blood tests were performed to evaluate the main alterations caused by both chemotherapeutic models. Dogs undergoing conventional chemotherapy had significant leukocyte changes $(p<0.05)$, causing neutropenia and leukopenia. In dogs undergoing metronomic chemotherapy, leukocytes remained within the reference range. Half of the dogs in group G1 had normochromic, normocytic anemia. The only biochemical alteration observed was the increase of urea in group G2. Thus, metronomic chemotherapy for the treatment of TVT with vincristine sulfate proved to be an excellent method for treatment, with fewer adverse effects, especially in maintaining the leukogram of dogs within normal range and reducing the number of anemia in animals during treatment.

INDEX TERMS: Hematology, biochemistry, chemotherapy, metronomic chemotherapy, treatment, canine transmissible venereal tumor, TVT, vincristine sulfate, oncogenesis, anemia, leukopenia, dogs.
\end{abstract}

RESUMO.- [Comparação entre as alterações hematológicas e bioquímicas ocasionadas pela quimioterapia convencional e quimioterapia metronômica no tratamento do tumor venéreo transmissível canino.] Esta pesquisa teve como objetivo relatar as alterações hematológicas e bioquímicas causadas pelo tratamento quimioterápico convencional e pela quimioterapia metronômica, utilizando-se sulfato de vincristina para o tratamento do tumor venéreo transmissível canino(TVTC). Foram selecionados 12 cães, sendo seis para o grupo que recebeu quimioterapia convencional (G1) e seis cães

\footnotetext{
${ }^{1}$ Received on June 10, 2020.

Accepted for publication on July 5, 2020

${ }^{2}$ Professor, Curso de Medicina Veterinária, Instituto Federal Farroupilha (IFFar), Frederico Westphalen, RS 98400-000, Brazil. *Corresponding author: paulo.braz@iffarroupilha.edu.br

${ }^{3}$ Graduate Program in Veterinary Science, Universidade Federal de Mato Grosso do Sul (UFMS), Campo Grande, MS 79070-900, Brazil.
}

para o grupo que recebeu quimioterapia metronômica (G2). 0 grupo G1recebeu sulfato de vincristina, uma vez por semana, na dose de $0,75 \mathrm{mg} / \mathrm{m}^{2}$, até o desaparecimento do tumor e o grupo G2 foi tratado com sulfato de vincristina, três vezes por semana, na dose de $0,25 \mathrm{mg} / \mathrm{m}^{2}$, até o desaparecimento do tumor. Antes e após o tratamento quimioterápico foram realizados exames hematológicos e bioquímicos sanguíneos para avaliação das principais alterações causadas pelos dois modelos quimioterápicos. Os cães submetidos à quimioterapia convencional tiveram alterações leucocitárias significativas $(p<0,05)$, causando uma leucopenia por neutropenia enquanto nos cães, submetidos à quimioterapia metronômica, os leucócitos mantiveram-se dentro do intervalo de referência. A metade dos cães do grupo G1 tiveram uma anemia do tipo normocítica normocrômica. A única alteração bioquímica observada foi o aumento da ureia no grupo G2. Desta forma, a quimioterapia metronômica para o tratamento do TVT 
com sulfato de vincristina, demonstrou ser um excelente método para a cura do animal, com menores reduções de efeitos adversos, sobretudo, na manutenção do leucograma dos cães e na redução de animais com anemia.

TERMOS DE INDEXAÇÃO: Hematologia, bioquímica, quimioterapia, quimioterapia metronômica, tratamento, tumor venéreo transmissível canino, sulfato de vincristina, oncogênese, anemia, leucopenia, caninos.

\section{INTRODUCTION}

Chemotherapy is a systemic drug model used to treat oncogenic processes (Skipper et al. 1970). This type of therapy is known for its cytotoxic effect, mainly due to the high doses administered to patients (Mutsaers 2009).

As an alternative to minimize the side effects of conventional chemotherapy, studies with metronomic chemotherapy started approximately two decades ago (Browder et al. 2000, Hanahan et al. 2000, Klement et al. 2000), characterized by the treatment of tumors using small doses of chemotherapy for longer periods, without interruption in treatment.

In dogs with canine transmissible venereal tumor (TVT) development, conventional vincristine sulfate chemotherapy is the best-known therapy with an effective outcome (Sudjaidee et al. 2012, Otter et al. 2015). However, there are reports of hematological disorders such as, anemia, thrombocytosis, leukopenia, and also lymphopenia (Kabuusu et al. 2019).

This study aimed to report the hematological and biochemical changes caused by conventional and metronomic chemotherapies, using vincristine sulfate to treat canine TVT.

\section{MATERIALS AND METHODS}

Dogs with a cytological diagnosis of canine transmissible venereal tumor (TVT) from the clinical care of a teaching hospital were selected for this study, without restriction of sex, age or breed. Cytological collection was performed using the technique of fine needle aspiration, imprint or scarification of the lesion, which was chosen according to the type of tumor.

Twelve dogs were selected, six of them for the group that received conventional chemotherapy (G1) and six for the group that received metronomic chemotherapy (G2). The pet owners were instructed on the experimental model used and signed a consent form for dogs treatment. If the animal had any side effect of chemotherapy, it would be removed from the project. The selected dogs were divided into two distinct groups:

G1: Application of vincristine sulfate, once a week, at the dose of $0.75 \mathrm{mg} / \mathrm{m}^{2}$, until the tumor had disappeared.

G2: Application of vincristine sulfate, three times a week, at the dose of $0.25 \mathrm{mg} / \mathrm{m}^{2}$, until the tumor had disappeared.

Before the initial chemotherapy treatment, in venous blood sampling, a needle was inserted to access the jugular vein, for hematological examinations and biochemical tests of alanine aminotransferase, alkaline phosphatase, urea, and creatinine. The tests were repeated immediately before each chemotherapy session to assess the animal. Nodular volume reduction and absence of round and vacuolated cells were seen in the cytopathological examination, confirming the end of treatment.

To compare groups G1 and G2, before starting the treatment and after cancer treatment has been effective in the dogs, paired sample t-test was used, with a 95\% significance level. The experiment was approved by CEUA-Unigran (Protocol 13-2016).

\section{RESULTS}

Among the groups studied, it was possible to analyze that there was a difference $(p>0.05)$ in the total leukocyte count (TLC), when comparing conventional and metronomic chemotherapy (Table 1), with a reduction in the total leukocyte count in the group that received conventional chemotherapy. In dogs that underwent metronomic chemotherapy, the leukocyte reduction has not shown during this treatment, favoring the maintenance of the chemotherapy cycle, until the tumor disappeared.

When performing the leukocyte differential, it was possible to notice that the animals underwent conventional chemotherapy had a reduction in the amount of segmented neutrophils $(p>0.05)$, presenting a neutropenia leukopenia at the end of the treatment. However, the same did not occur with dogs treated with vincristine sulfate with respect to the metronomic model. The leukocyte and neutrophil counts have been noted until the end of the treatment of the animals. Lymphocytes, monocytes, eosinophils and basophils were not influenced by any of the groups, maintaining within the reference value for the species (Table 1).

When comparing the two treated groups, it was observed that the erythrogram did not change in any of the groups $(p>0.05)$, with no influence on the total red blood cell (RBC) count, hematocrit and hemoglobin levels (Table 1). However,

Table 1. Mean values, standard deviation, and $p$-value obtained by the t-test of the paired sample of the blood count of animals underwent conventional (G1) and metronomic (G2) chemotherapies before and after the beginning of treatment

\begin{tabular}{|c|c|c|c|c|c|c|c|c|c|c|}
\hline \multirow{3}{*}{ Blood count } & \multicolumn{5}{|c|}{ Conventional chemotherapy } & \multicolumn{5}{|c|}{ Metronomic chemotherapy } \\
\hline & \multicolumn{2}{|c|}{ Mean } & \multicolumn{2}{|c|}{ SD } & \multirow{2}{*}{$p$ value } & \multicolumn{2}{|c|}{ Mean } & \multicolumn{2}{|c|}{ SD } & \multirow{2}{*}{$p$ value } \\
\hline & Before & After & Before & After & & Before & After & Before & After & \\
\hline Total leukocytes & 18,416 & 7,750 & 7,205 & 3,939 & 0.005 & 19,066 & 8,200 & 11,879 & 3,646 & 0.08 \\
\hline Neutrophils & 12,671 & 4,803 & 4,491 & 4,257 & 0.03 & 14,366 & 5,272 & 7,977 & 2,359 & 0.07 \\
\hline Lymphocytes & 963 & 1.191 & 872 & 691 & 0.17 & 3,612 & 1,109 & 3,870 & 7.53 & 0.20 \\
\hline Monocytes & 478 & 421 & 248 & 320 & 0.61 & 646 & 279 & 615 & 415 & 0.38 \\
\hline Erythrocytes & 5.49 & 4.98 & 1.13 & 1.24 & 0.24 & 5.90 & 5.12 & 1.56 & 1.12 & 0.34 \\
\hline Hematocrit & 36.2 & 33.4 & 7.39 & 9.03 & 0.27 & 36.9 & 33.8 & 6.7 & 9.8 & 0.43 \\
\hline RDW & 14.81 & 15.88 & 2.54 & 2.71 & 0.12 & 12.3 & 13.8 & 0.9 & 1.4 & 0.07 \\
\hline Platelets & 229,333 & 244,000 & 122,670 & 153,367 & 0.87 & 199,500 & 171,833 & 127,694 & 137,389 & 0.76 \\
\hline
\end{tabular}

SD = standard deviation, RDW = red cell distribution width 
when analyzing the animals individually, it was possible to notice that in the group that underwent conventional chemotherapy, i.e., the anemia of the normocytic and normochromic type occurred in three animals, whereas, among the dogs underwent metronomic chemotherapy, a discrete anemia of the normocytic type and normochromic occurred in one animal with a hematocrit of $33 \%$.

In the two groups studied, the red cell distribution width (RDW) remained stable during chemotherapy. This demonstrated that during treatment, it could be noted a reduction in red cells production, justifying normocytic and normochromic anemia. Similarly, it was observed that there was stability in the total platelet count, remaining from the beginning to the end of the treatment within the reference value for the species (Table 1).

When analyzing the serum biochemical assays of alanine aminotransferase (ALT), alkaline phosphatase, creatinine and urea, all remained stable during chemotherapy, except for urea (Table 2). Animals that underwent metronomic chemotherapy had a significant increase $(p<0.05)$ in their baseline value, although, the serum level in all animals was within the reference value for the species.

\section{DISCUSSION}

In a conventional chemotherapy treatment, the maximum tolerable dose of the drug administered is used to destroy the largest number of cells. Some drugs, through a secondary mechanism, also inhibit tumor angiogenesis (Browder et al. 2000). Based on the concept of maximum tolerable dose (MTD), classical chemotherapy can cause damage and cytotoxicity both in neoplastic and healthy tissues, such as bone marrow (BM). Potential side effects are seen in the time interval between drug applications, and support with drugs are also required (Mutsaers 2009).

There are several mechanisms of action generated for metronomic chemotherapy. One example is associated to the administration of lower doses of chemotherapy continuously that allows effective control of endothelial precursor cells released from the $\mathrm{BM}$ and reaches the development of a tumor area. These precursor cells are not neoplastic tissues, but they do allow the development of primary tumor masses and their distant metastases (Polton 2014).

Among the main advantages of metronomic chemotherapy are related to significant activity against the parenchyma and stroma of the neoplastic cells, in addition to providing less systemic side effects, less chance of resistance to the chemotherapy drug, greater pro-apoptotic and antiangiogenic activities, low acute toxicity, possibility of administration of the drug for a long time and the possibility of combining with other drugs (Mutsaers 2007).

Vincristine has a known neurotoxicity effect, considered the main side effect observed. This effect generates neutropenia associated with vinca alkaloids which corresponds to doselimiting toxicity (DLT) (Ishikawa et al. 2009). Since neutrophils are the most abundant leukocyte cells, it is expected that, as shown in this study, leukopenia may occur due to neutropenia. The decline in neutrophils is associated to the action of cytotoxic drug that suppressed the precursor of BM cell replicating and developed myeloid toxicity. One of the main reasons for this reduction in the leukocyte count is owing to myelosuppression.

Some components of vinca extract can cause peripheral blood leukopenia and myelosuppression (Zhang et al. 2018). These side effects to spinal hypoplasia were not observed in dogs underwent metronomic chemotherapy. In cases where the animal has an intense leukopenia during the chemotherapy, the treatment must be suspended until the total leukocyte count is elevated (Vail 2009).

By analyzing the results of individual blood count, half of the animals had a normocytic and normochromic anemia type when treated with conventional chemotherapy. These data are reported by other authors (Nak et al. 2005, Kabuusu et al. 2019). Like leukocytes, the global RBC count declines due to the consequent suppressive effect on BM caused by this cytotoxic drug (Sandhu 2006).

In addition to the total erythrocyte count in dogs affected by TVT, the RDW tends to remain within the reference values without showing an increase in cell diameter, characteristic of young cells due to spinal cord regeneration. Even during the post-treatment period, chemotherapeutic agents may act by suppressing erythropoiesis in the BM (Jumean et al. 1979, Yadav et al. 2018).

Serum levels of ALT and alkaline phosphatase did not have a statistical difference $(p>0.05)$. However, when comparing the animals of groups G1 and G2, before the beginning of chemotherapy treatment and the vincristine sulfate at the end of treatment (Table 2), as well as analyzing the individual results, it was possible to notice an increase in these values, even though, they remained within the reference range for the species. Cytotoxic drugs were deposited in the BM and then detoxified by the liver. Thus, it could be noted a type of liver disease with significant release of these enzymes (Amruth Kumar et al. 2018).

Creatinine remained unchanged, both in the G1 and G2 groups, although urea increased $(p<0.05)$ in the G2 group (Table 2). This physiological increase in urea may be linked to the increase in protein catabolism caused due to tubular

Table 2. Mean values, standard deviation, and $p$-value obtained by the paired sample t-test of biochemical tests of animals underwent conventional (G1) and metronomic (G2) chemotherapies before and after the begining of treatment

\begin{tabular}{|c|c|c|c|c|c|c|c|c|c|c|}
\hline \multirow{3}{*}{ Biochemicals } & \multicolumn{5}{|c|}{ Control group } & \multicolumn{5}{|c|}{ Experimental group } \\
\hline & \multicolumn{2}{|c|}{ Mean } & \multicolumn{2}{|c|}{ SD } & \multirow{2}{*}{$p$ value } & \multicolumn{2}{|c|}{ Mean } & \multicolumn{2}{|c|}{ SD } & \multirow{2}{*}{$p$ value } \\
\hline & Before & After & Before & After & & Before & After & Before & After & \\
\hline ALT & 47.1 & 45.5 & 27.9 & 8.4 & 0.88 & 26.6 & 34.1 & 17.3 & 11.1 & 0.08 \\
\hline Alkaline phosphatase & 37.1 & 54.8 & 26.3 & 33.2 & 0.33 & 78.3 & 109.1 & 45.9 & 80.1 & 0.41 \\
\hline Creatinine & 1 & 1 & 0 & 0 & 0.61 & 0.8 & 1 & 0 & 0 & 0.28 \\
\hline Urea & 31 & 45.1 & 9.5 & 17 & 0.17 & 28.5 & 40.5 & 10.1 & 10.3 & 0.02 \\
\hline
\end{tabular}

$\mathrm{SD}=$ standard deviation, $\mathrm{ALT}=$ alanine aminotransferase. 
necrosis, considered a side effect of chemotherapy (Birhan \& Chanie 2015). In addition, as the molecular formula of vincristine sulfate has in its structure four nitrogen molecules (C46H58N409) and nitrogen is excreted in the form of urea, the increased frequency of chemotherapy use, associated with its half-life, may cause elevated blood urea. This increasing level was kept within the reference range (Zhang et al. 2018).

\section{CONCLUSIONS}

Metronomic chemotherapy for the treatment of canine TVT using vincristine sulfate has proved to be an excellent method for treatment of the animals. This method presented fewer adverse effects, especially in maintaining the leukogram of dogs and reducing the number of anemia in animals during treatment. It can be inferred that this type of therapy causes less damage to the bone marrow when compared to conventional chemotherapy.

There must be a greater commitment from the pet owners in order to be able to carry out the chemotherapy protocol without interruptions since, every two days, the new chemotherapy session will be given to the animal.

Conflict of interest statement.- The authors have no competing interests.

\section{REFERENCES}

Amruth Kumar V.V.V., Kumari K.N., Kumar K.S., Kumar V.G. \& Lakshman M. 2018. Effect of Vincristine chemotherapy in TVT affected dogs. Pharma Innovation J. 7(4):163-166.

Birhan G. \& Chanie M. 2015. A review on canine transmissible venereal tumour from morphologic to biochemical and molecular diagnosis. Acad. J. Anim. Dis. 4(3):185-195. <https://dx.doi.org/10.5829/idosi.ajad.2015.4.3.95245>

Browder T., Butterfield C.E., Kräling B.M., Shi B., Marshall B., O’Reilly M.S. \& Folkman J. 2000. Antiangiogenic scheduling of chemotherapy improves efficacy against experimental drug-resistant cancer. Cancer Res. 60(7):18781886. <PMid:10766175>

Hanahan D., Bergers G. \& Bergsland E. 2000. Less is more, regularly: metronomic dosing of cytotoxic drugs can target tumor angiogenesis in mice. J. Clin. Invest. 105(8):1045-1047. <https://dx.doi.org/10.1172/ JCI9872><PMid:10772648>

Ishikawa H., Colby D.A., Seto S., Va P., Tam A., Kakei H., Rayl T.J., Hwang I. \& Boger D.L.J. 2009. Total synthesis of vinblastine, vincristine, related natural products, and key structural analogues. Am. Chem. Soc. 131(13):4904-4916. <https://dx.doi.org/10.1021/ja809842b > <PMid:19292450>

Jumean H.G., Camitta B., Holcenberg J. \& Hodach A. 1979. Desacetyl vinblastine amide sulfate induced erythropoiesis. Cancer 44(1):64-68. <https://dx.doi. org/10.1002/1097-0142(197907)44:1>64::aid-cncr2820440112>3.0.co;2-5> $<$ PMid:455265>

Kabuusu R.M., Kumthekar S., Tang J., Alexander R., Sylvester W., LanzaPerea M. \& Sharma R.N. 2019. Clinicopathological changes during canine transmissible venereal tumor treatment with vincristine. Indian J. Vet. Pathol. 43(2):132-135. <https://dx.doi.org/10.5958/0973-970X.2019.00027.0>

Klement G., Baruchel S., Rak J., Man S., Clark K., Hicklin D.J., Bohlen P. \& Kerbel R.S. 2000. Continuous low-dose therapy with vinblastine and VEGF receptor-2 antibody induces sustained tumor regression without overt toxicity. J. Clin. Invest. 105(8):R15-R24. <https://dx.doi.org/10.1172/ JCI8829><PMid:10772661>

Mutsaers A.J. 2007. Chemotherapy: new uses for old drugs. Vet. Clin. N. Am., Small Anim. Pract. 37(6):1079-1090. <https://dx.doi.org/10.1016/j. cvsm.2007.07.002 > <PMid:17950883>

Mutsaers A.J. 2009. Quimioterapia metronômica. Top. Comp. Anim Med. 24(3):137-143.

Nak D., Nak Y., Cangul T. \& Tuna B. 2005. A clinico-pathological study on the effect of vincristine on transmissible venereal tumour in dogs. J. Vet. Med. Ser. A 52(7):366-370.<https://dx.doi.org/10.1111/j.1439-0442.2005.00743.x> $<$ PMid:16109105>

Otter W.D., Hack M., Jacobs J.J., Tan J.F., Rozendaal L. \& Van Moorselaar R.J. 2015. Effective treatment of transmissible venereal tumors in dogs with vincristine and IL2. Anticancer Res. 35(6):3385-3391. <PMid:26026099>

Polton G. 2014. Novel drug approaches in veterinary cancer therapy. Vet Ireland J. 4(1):27-32.

Sandhu H.S. 2006. Essentials of Veterinary Pharmacology and Therapeutics. $2^{\text {nd }}$ ed. Kalyani Publishers, New Delhi, p.1359-1381.

Skipper H.E., Schabel Jr F.M., Mellett L.B., Montgomery J.A., Wilkoff L.J., Lloyd H.H. \& Brockman R.W.1970. Implicações das relações bioquímicas, citocinéticas, farmacológicas e toxicológicas no desenho de horários terapêuticos ideais. Cancer Chemother. Rep. 54(6):431- 450. <PMid:5527023>

Sudjaidee P., Theewasutrakul P., Techarungchaikul S., Ponglowhapan S. \& Chatdarong K. 2012. Treatment of canine transmissible venereal tumor using vincristine sulfate combined with L-asparaginase in clinical vincristine-resistant cases: a case report. Thai J. Vet. Med. 42(1):117-122.

Vail D.M. 2009. Supporting the veterinary cancer patient on chemotheraphy: neutropenia and gastrointestinal toxicity. Topic Comp. Anim. 24(3):122129. <https://dx.doi.org/10.1053/j.tcam.2009.02.004><PMid:19732730>

Yadav A., Bugalia N.S., \& Pandey A.K. 2018. Haemato-biochemical and therapeutic evaluation of doxorubicin and vincristine in canine transmissible venereal tumour. Indian J. Anim. Reprod. 39(2):40-42.

Zhang Y.W., Kong X.Y., Wang J.H. \& Du G.H. 2018. Vinblastine and vincristine, p.551-557. In: Du D-.H. Natural Small Molecule Drugs from Plants. Springer, Singapore. <https://dx.doi.org/10.1007/978-981-10-8022-7_91> 